\title{
Consistency and Harmonization of Village Fund Management in Indonesia (Case Study in Tulus Rejo Village and Kecapi Village)
}

\author{
Siti Khoiriah \\ Law Faculty \\ Lampung University \\ Lampung, Indonesia \\ Siti.khoiriah@fh.unila.ac.id
}

\author{
Luzman Qashmal \\ Law Education \\ Lampung University \\ Lampung, Indonesia \\ Luzman.qashmal128019@students.unila.
} ac.id

\author{
Ryzal Perdana \\ Educational Science \\ Lampung University \\ Lampung, Indonesia \\ Ryzalperdana2009@gmail.com
}

\begin{abstract}
Dealing with the implementation of village finances, many arrangements in legislation ranging from laws to village head regulations have been found. In every hierarchy of laws and regulations, there should be harmonization between laws and regulations following the legal principle of lex superior derogat legi inferiori. This article revealed that the village financial system in Indonesia was fully harmonized and complements each other, especially it will have an impact on and focus on the implementation of the Tulus Rejo village and the Kecapi Village. Village finances differ from one another with a percentage weight that determines the number of village finances. Besides, the village concept can affect the village finances. Village finances have almost the same scope of management as compared to the financial management of the central government to provincial, district, and city governments.
\end{abstract} LSG

Keywords - village finance, smart village, SCG and

\section{INTRODUCTION}

The enactment of Law Number 6 of 2014 concerning Villages has a legal impact on village consistency and it provides attention to villages so that the village is independent in managing its government with the principles of good governance. Seeing from the issue, the regional and central governments are not completely hands-off, as evidenced by the flow of APBN-P funds for villages, which is Rp. 20,776 T. With this realization, a village government is formed with indicators to become an advanced and independent village government. Besides, the implementation of Law Number 6 of 2014 concerning Villages, many implementing regulations have been issued in the form of government regulations, ministerial regulations, provincial-level regulations, governor regulations, regent regulations to the regulation of village heads.

\section{DISCUSSION}

In discussing the laws and regulations from the highest to the lowest, we can see 2 levels of government, namely the central government and local governments.

The Central Government should have a very main and strategic role in determining village policies [1]. Besides, getting a mandate to allocate Village Funds in the APBN, there are other major influences in the form of guidance and supervision to subordinates. The definite guidance and supervision by the Central Government is regulated in Article 113 of the Village Law, including: Create guidelines clearly and implementation standards for Village Administration;

- Create guidelines for funding efforts from the Government, Provincial Government, and City/Regency Regional Government to villages;

- Maximize appreciation, guidance, and coaching at village community institutions;

- Establish guidelines for the preparation of development planning that are always participatory;

- Determine clear guidelines for standardizing positions for village officials regarding village funds;

- Facilitate guidance, supervision, and consultation on the implementation of Village Government, Village Consultative Body, and community institutions for clarity of village funds;

- Provide financial assistance directly to the village; 
- Facilitate education and training for Village Government apparatus and Village Consultative Body.

- Conduct research on the implementation of Village Government in certain villages;

- Encourage the acceleration of rural development;

- Facilitate and research in the context of determining the customary law community unit as a village;

- Develop and facilitate technical guidelines for BUM Desa and village cooperation institutions.emerintah Daerah Provinsi

The Government of Province affects the role in monitoring and fostering the village which is regulated in Article 114 of the Village Law, including:

- Guide regencies/municipalities in the context of drafting the relevant Regency/City Regional Regulations regulating village and village funds;

- Guide districts/cities in the context of granting Village Fund Allocations;

- Conducting coaching to increase the capacity of village heads and village officials, Village Consultative Body, and community institutions;

- Conducted guidance to streamline village government management;

- Conducted guidance so that village development can be carried out quickly from financial assistance, village fund assistance, and technical assistance must proceed properly;

- Hold a full inventory of which provincial authority will be implemented by the village;

- Conducted guidance and supervision on the determination of the Draft Regency/Municipal Regional Revenue and Expenditure Budget in village financing;

- Guide regencies/municipalities in the context of structuring village areas;

The law has been set o far as Law Number 6 of 2014 concerning Villages, where this Law adheres to the principles of deliberative democracy and the incorporation of hybrid concepts (SCG and LSG) into a new village order. It means that the new village must involve the community and the view of the village becomes subjective. Therefore, the principles in managing village funds in the Village Law are recognition, subsidiarity, diversity, togetherness, cooperation, kinship, deliberation, democracy, independence, participation, equality, empowerment, and sustainability.
In the planning and budgeting stage, the village government should include the village community with the agreement of the Village Consultative Body (BPD), therefore the activities compiled must be following the interests and needs of the village community and be in line with the capabilities possessed in the village.

A. Government Regulation Number 60 of 2014

Revised by PP No. 8 of 2018 concerning Village

Funds Sourced from the State Budget.

1) Village Fund Allocation Procedures

In reviewing this Government Regulation on the management of village funds, it can be seen from Article 11 paragraphs (1)-(5) that there are rules for the allocation of village funds which are systematic by reviewing the distribution so that a multiplication limit is formed from the total population, area, and poverty rate. , calculated by weight:

- $30 \%$ (thirty percent) for the total population of the regency/city;

- $20 \%$ (twenty percent) for the area of the regency/city; and

- $50 \%$ (fifty percent) for district/city poverty rates.

Therefore, each village is different in receiving village funds from the APBN. From the weight above, the systematics of the national Village Fund determined in the APBN are $(30 \%$ x percentage of the total population of districts/cities to the total national population $)+(20 \%$ x percentage of the total area of regencies/cities to the total national area $)+(50 \% \mathrm{x}$ percentage of the number of poor people in districts/cities to the total number of poor people nationwide.

\section{2) The Procedure of Village Fund Distribution}

Following the rules in Articles 16 and 17, the distribution of village funds is gradual and carried out no later than 7 (seven) working days after it is received in the regional general treasury account (RKUD).

3) Procedures for using village funds

Article 19-22 asserts that the use of village funds is to finance the administration of government, development, community empowerment, and society with development and community empowerment priorities. In this procedure, the village must determine the priority of using village funds for its village for 2 months which is then designed as a guideline. and coordinate with the minister in charge of national planning and development before the fiscal year.

B. Government Regulation Number 43 of 2014 concerning Implementing Regulations of Law Number 6 of 2014 concerning Villages

In this government regulation regarding village funds, some things must be considered, namely: 


\section{1) Village Finance Management}

Villages receive village funds from the APBN and APBD and Article 93 states that managing village funds is carried out with the flow of planning, implementation, administration, reporting, and accountability [2]. Article 94 provides information related to 1 budget period, namely January 1 to December 31 .

\section{2) Fund Allocation Procedure}

The percentage of the allocation of funds from the APBN and APBD is different, in the APBD, it is 10\% of the balancing funds received by regencies/municipalities in the regional revenue and expenditure budget after deducting special allocation funds. But some are harmonious (consistent) with the previous PP, which is still using the differences in each village from the factors of the number of village residents, the poverty rate of the village, the area of the village, and the level of geographical difficulty of the village.

\section{Level Rules of Minister about the Village Fund}

In government regulations related to village funds, on the other hand, there are ministerial-level regulations regarding the use of village funds, although hierarchically the ministerial-level regulations are not recognized, the substance in ministerial regulations is still used considering that in government regulations there are several articles that state that they must be re-regulated in regulations that level. minister.

1) Ministry of Villages, PDT and Transmigration

The latest Minister of Village, Ministry of Village, PDT, and Transmigration regulations related to village funds during the pandemic, namely Minister of Village, PDT and Transmigration Regulation Number 13 of 2020 concerning Priority for Use of Village Funds in 2021.

In this regulation, the priority of using village funds is now more on restoring the village economy considering the impact of covid-19. The regulation clearly states "The Village Government is obliged to involve the community in determining the Priority for the Use of Village Funds" which means that every village in Indonesia uses the SCG system for village funds.

Seeing from government regulations, there must be accountability results, therefore at the ministerial level regulation that reporting must be published in the village public space and must contain at least the name of the activity, location of the activity, and the amount of the budget

\section{2) Ministry of Internal Affairs}

Minister of Home Affairs Regulation Number 113 of 2014 concerning Village Financial Management. In the management of classified village funds starting from planning, implementation, administration, and reporting. In the village fund reporting section, there is a special provision in which the Village Head submits a report on the realization of the APBDesa implementation to the Regent/Mayor in the firstsemester report and year-end semester report.

The substance of the first-semester report is in the form of the APBDesa realization report and harmonization with the Minister of Village Regulation that reporting on village funds must be published in writing and with information media that is easily accessible by the public.

\section{Provincial Regulation/Governor Regulation of Lampung concerning Village Fund Management}

1) Lampung Province Regional Regulation Number 7 of 2007 concerning Principles of Regional Financial Management Development Planning

In this regulation, the focus is on village finance. The principles of village finance are efficiency, economy, effectiveness, transparency and responsibility, fairness, propriety, and benefit. The most important principle is transparency, fairness, and benefit. With the above principles, village funds can proceed properly. This regulation also explains the importance of the people to have transparency in their regional funds. Implicitly Article 35 paragraph (2) financial management of regional planning is carried out through village planning deliberations (musrenbangdes).

2) Regulation of Governor Regarding the Establishment of the Lampung Province Village Fund Development and Supervision Task Force in 2017

In the Lampung Governor Regulation regarding village funds, there are 3 points, namely:

- Establish Village Fund Development and Supervision toward village finance with the personnel structure in Lampung Province 2017

- The village fund supervisory unit team, namely:

- Coach

The task is to guide the task force team for the guidance and supervision of village funds to make the program increase community participation in village development success and to supervise the implementation of the tasks of each SKPD so that it is carried out properly according to the plan.

-Leader. The person has the task of coordinating all programs and activities for fostering and supervising the implementation of village funds in all regencies throughout the province of Lampung and is Responsible for all programs and activities to be implemented.

- Member. The task of members is to monitor the use of village funds starting from the planning, 
implementation, and accountability process of village funds, handling complaints related to the implementation of village funds, providing guidance and supervision to districts in the framework of drafting Regional Regulations and Regent Regulations that regulate Villages, conducting guidance and supervision of Districts in the context of providing village fund allocations; and conduct guidance and supervision of Village Government management.

- The village fund supervisory team must report the results of the implementation of the village fund management to the governor.

\section{E. District/City Regional Regulations concerning} Village Fund Management East Lampung Regent Regulation Number 12 of 2016 concerning Guidelines for Village Financial Management

In East Lampung Regent Regulation Number 12 of 2016 concerning Guidelines for Village Financial Management, it provides the scope for managing village funds which are already listed by government regulations but with the designation of the flow of funds are planning, implementation, administration, reporting, and accountability [3].

The general principle of the village budget (APB Desa) contains the essence of planning for supervision, allocation, distribution, and stabilization [4]. Reviewing from the village minister's regulation that there are technicalities in the preparation of the report but it is also regulated by the regent's regulation which is the making of the village fund structure, namely village income, village expenditure, and village financing.Desa Tulus Rejo, Sub-district of Pekalongan Regency of East Lampung [5].

Tulus Rejo village is a smart village. This is following the opinion of the village head, Mr. Hartono "With the smart village program, village administration services are integrated, directing village market management, community empowerment, and developing tourism potential online,". Until now, Tulus Rejo Village has prioritized the smart village program following the Lampung Governor's Decree No. G/228/II.02/2020 dated April 17, 2020, regarding the Determination of the Target Location of the 2020 Smart Village Pilot Project in Lampung Province, Tulus Rejo Village should be designated as a pilot project in a smart village. The Tulus Rejo Village Regulation related to village funds is the Tulus Rejo Village Head Regulation Number 1 of 2021 concerning the Elaboration of the Tulus Rejo Village Revenue and Expenditure Budget for the 2019 Fiscal Year. Tulus Rejo Village has implemented the principles of transparency, efficiency, and benefit. this is evidenced by the information that the author obtained as follows:
APBDes 2021 Implementation

Realization I Budeet

INCOME

Rp. $814,393,238$ | Rp. 1,643,386,107

EXPENSES

Rp. $804,890,749$ | Rp. $1,658,098,734$

FINANCING

Rp. $14,712,627 \mid$ Rp. $14,712,627$

${ }^{\text {a. }}$ Source: siskeudes sincererejo.id.

Fig. 1. APBDes 2021 Implementation

It can be seen in the data above that the budget requirements have been met according to the regulations (village income, village expenditure, and village financing), by understanding the data above that the blue line is for stating realization and the red line is unrealized (unused) and for this, it is still an overall picture. common in the village. In the opinion of Tulus Rejo Village, it is Rp. 1,643,386,107, but village spending is limited to Rp. 1,658,098,734 and financing of Rp. 14,712,627. However, there is an oddity that village spending is greater than village income which should be balanced.

- The Income of Tulus Rejo Village

There are several details of the income of Tulus Rejo Village which is a smart village as follows:

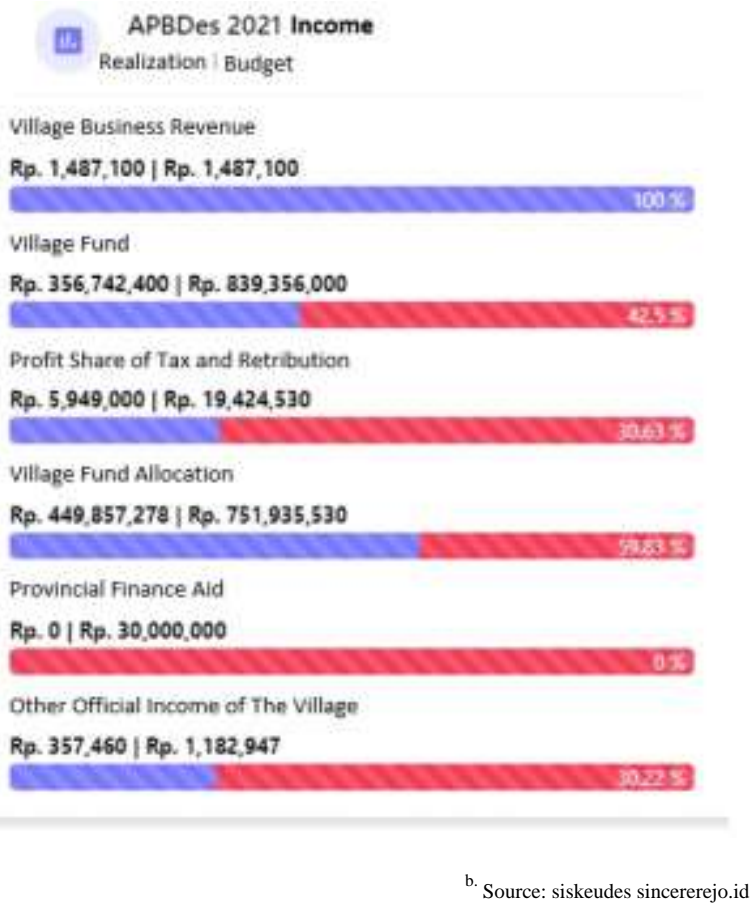

Fig. 2. APBDes 2021 Income 
In the table, the most income is from the results of the village business itself, even village funds look significantly smaller than the results of the village itself, so the author can review the since Rejo Village using the hybrid concept (LSG and SCG) which includes developed villages and has been harmonized / following Law Number 6 of 2014 concerning Villages, where Tulus Rejo is heading for a new village order. In addition, Tulus Rejo has indeed advanced, it was found that Tulus Rejo Village Head Regulation Number 1 of 2021, which is the result of community consultations and village heads, in this case, the village consultation body with the village head.

- The Expenditure of Tulus Rejo Village:

APBDes 2021 Expenses

Realization | Budget

MANAGEMENT DIVISION OF VILLAGE GOVERNMENT

Rp. $492,540,749$ | Rp. $806,360,234$

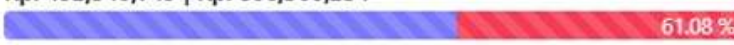

IMPLEMENTATION DIVISION OF VILLAGE DEVELOPMENT

Rp. $94,800,000$ | Rp. $417,680,500$

COMMUNITY GUIDANCE DIVISION

Rp. $83,000,000 \mid$ Rp. $141,348,000$

COMMUNITY EMPOWERMENT DIVISION

Rp. $8,550,000$ | Rp. $40,710,000$

DIVISION OF DISASTER, EMERGENCY, AND URGENCY MANAGEMENT IN THE VILLAGE

Rp. $126,000,000 \mid$ Rp. $252,000,000$

Fig. 3. APBDes 2021 Expenses

In the study of Tulus Rejo Village, according to the current direction of the ministry, it should be expanded to the community's economy considering the total population of around 3,526 people in Tulus Rejo Village, this is because the COVID-19 pandemic has had a major impact on the country's economy and even internationally [6].

\section{F. Kecapi Village, Kalianda District, South Lampung Regency}

In Kecapi Village, this village has a vision and mission, namely "Senggigi Seria" Clean, Religious, Prosperous, Neat, and Beautiful [7]. Through Development Acceleration based on Religion, Legal Culture and Environmentally Insight with an orientation on improving Apparatus Performance and Community Empowerment.

The mission and work program of Senggigi Village are:
And to implement the vision of Senggigi Village, the following missions and programs are implemented:

1) Long Term Development

- Continue the village development that has not yet been implemented.

- Increase cooperation between village government and existing village institutions.

- Improve the welfare of the village community by improving the economic facilities and infrastructure of the residents.

2) Short Term Development

- Develop and maintain and preserve village customs, especially those that have taken root in Senggigi village.

- Improve services in the field of government to citizens

- Improve the economic facilities and infrastructure of the villagers by improving the economic infrastructure and facilities.

- Improve educational facilities and infrastructure to increase the human resources of Senggigi Village.

This village is a smart village and has used a hybrid concept (SCG and LSG) and the transparency of village funds is visible, it can be indicated in the regulation of Kecapi Village Head Number 1 of 2021 concerning the Elaboration of the Kecapi Village Revenue and Expenditure Budget for the 2021 Fiscal Year. The consideration in this rule is that this APBDes is carried out openly and responsibly for the prosperity of the village society. Kecapi village has a village income in 2021 of Rp. 1,342,701,720.00 and the village expenditure is Rp. 1,326,680,814 and the financing is Rp. 30,000,000 for the latest information on village funds that were realized for repairing the kecapi village road which cost Rp. 76,694,275.

\section{REFERENCES}

[1] BPKP. "Petunjuk Pelaksanaan Bimbingan Dan Konsultasi Pengelolaan Keuangan Desa." Badan Pengawasan Keuangan Dan Pembangunan (BPKP), 2015. Trans. Roy. Soc. London, vol. A247, pp. 529-551, April 1955. (references)

[2] Pasal 90 Peraturan Pemerintah No 43 tahun 2014 Peraturan Pelaksanaan Undang-undang Nomor 6 Tahun 2014 tentang Desa

[3] Pasal 4 Peraturan Bupati Lampung Timur No 12 Tahun 2016 tentang Pedoman Pengelolaan Keuangan Desa

[4] Pasal 14 Peraturan Bupati Lampung Timur No 12 Tahun 2016 tentang Pedoman Pengelolaan Keuangan Desa.

[5] Pasal 19 Peraturan Bupati Lampung Timur No 12 Tahun 2016 tentang Pedoman Pengelolaan Keuangan Desa.

[6] Desa Tulusrejo Kembangkan Smart Village - Desa Membangun 
[7] http://desa.lampungpost.id/desa-tulusrejo-kembangkansmart-village/Accessed: 2021-09-29

[8] Website Resmi Desa Kecapi Kecamatan Kalianda Kabupaten Lampung Selatan https://kecapi.smartvillage.co.id/index/2 Accessed: 2021-09-29 